\title{
COMPETITIVENESS OF SAUERKRAUT PRODUCTION ${ }^{1}$
}

\author{
Marko Jeločnik ${ }^{2}$, Jonel Subić 3 , Vlado Kovačević ${ }^{4}$
}

\begin{abstract}
Vegetable production represents important segment of the Serbian agricultural output. Within the structure of produced vegetable, cabbage has significant share. Cabbage conservation, primarily for the winter period, in a form of sauerkraut (for preparation of salads and hot dishes) has long tradition both at national and international level. Sauerkraut production is usually in function of value added products generation at the farms oriented to vegetable production that boosts their long-term sustainability. The main goal of this article is to compare contribution margin gained at the farm involved in sauerkraut production made from conventionally or organically produced cabbage. One production year is observed (gained data refers to 2018). It could be concluded that pickling of organic cabbage allows creation of higher farm's income and contribution margin.
\end{abstract}

Key words: conventional and organic cabbage, sauerkraut production, contribution margin.

JEL5: Q12, Q19

\section{Introduction}

Cabbage (Brassica oleracea var. capitata) is perennial, cultivated, herbaceous plant gained through the selection of wild cabbage over a very long period (into the human nutrition and medicine was introduced during the ancient Greece in the $4^{\text {th }}$ century BC). Cabbage has a pronounced nutritional and medicinal value, as well as low calorie value. It is contained in the availability of certain useful phytochemicals,

1 Paper is a part of research at the project no. III 46006, financed by the Ministry of Education, Science and Technological Development of the Republic of Serbia, as well as the Project Advancement of knowledge transfer towards the approaching to safer and more competitive agricultural products gained by processing at small farms within the sector of milk, meat, fruit and vegetable, financed by the Ministry of Agriculture, Forestry and Water management of the Republic of Serbia.

2 Marko Jeločnik, Ph.D., Research Associate, Institute of Agricultural Economics, Volgina Street no. 15, 11060 Belgrade, Serbia, Phone: +381 116972 852, E-mail: marko_j@iep.bg.ac.rs

3 Jonel Subić, Ph.D., Principal Research Fellow, Institute of Agricultural Economics, Volgina Street no. 15, 11060 Belgrade, Serbia, Phone: +381 116972 863, E-mail: jonel_s@iep.bg.ac.rs

4 Vlado Kovačević, Ph.D., Research Associate, Institute of Agricultural Economics, Volgina Street no. 15, 11060 Belgrade, Serbia, Phone: +381 1169 72 858, E-mail: vlado_k@iep.bg.ac.rs

5 Article info: Original Article, Received: $1^{\text {st }}$ October 2019., Accepted: $14^{\text {th }}$ October 2019. 
such as indole-3-carbinol (I3C), sulforaphane, phenolic compounds, carotenoids or glucosinolates (antioxidants desirable for detoxification), as well as the most of vitamins (primarily $\mathrm{C}$, or $\mathrm{A}, \mathrm{B} 1, \mathrm{~B} 2, \mathrm{PP}, \mathrm{B} 6, \mathrm{~B} 12, \mathrm{P}, \mathrm{K}$ and $\mathrm{U}$ ), minerals $(\mathrm{Ca}, \mathrm{K}$, $\mathrm{S}$, etc.) and carbohydrates (mostly free sugars, starch, cellulose and hemicellulose), (Cvetković, 2014).

Cabbage significantly appears within the structure of vegetable production in Serbia. After potatoes, it occupies the largest production areas (Červenski, Medić Pap, 2018). It is most commonly used in human nutrition, as fresh or processed (usually as sauerkraut), for the preparation of various salads and meals. In the diet are used the head, leaf or juice of cabbage.

Cabbage is mainly cultivated at the small family farms, which dispose with at maximum 5 ha of production area. Production is dominantly turned to direct or natural consumption and industrial processing. On the other side, in the total volume of produced vegetables, cabbage is generally positioned around the $10^{\text {th }}$ place, where, as with other vegetables, annual production is insufficient to cover domestic demand (GRS, 2019).

The SORS collects and presents summarized production data for all brassica plants (cabbage and kale). From the data presented in the Table 1., it could be noticed that during the last 7 years (2012-2018), there has been a negative trend in the total harvested areas under the brassica plants. Oscillations related to yields and total production is primarily caused by the climatic factor (increase in deficit or bad spatial and temporal dispersion of rainfalls, or increase in average temperatures within the growing season), as cabbage production requires significant volume of water and frequent watering.

Table 1. Harvested surfaces, total production and average yields of cabbage and kale at national level (period 2012-2018)

\begin{tabular}{|c|c|c|c|}
\hline Year & Harvested area (in ha) & Total production (in t) & Yield (in t/ha) \\
\hline 2012. & 11,890 & 303,893 & 25.6 \\
\hline 2013. & 11,246 & 303,893 & 27.0 \\
\hline 2014. & 11,116 & 261,240 & 23.5 \\
\hline 2015. & 11,039 & 288,698 & 26.2 \\
\hline 2016. & 10,804 & 290,001 & 26.8 \\
\hline 2017. & 10,213 & 262,545 & 25.7 \\
\hline 2018. & 8,251 & 209,353 & 25.4 \\
\hline Average & 10,651 & 274,232 & 25.7 \\
\hline
\end{tabular}

Source: SORS, 2019. 
Although surfaces under organic production are still limited (less than $0.5 \%$ of utilized agricultural area), their growth has positive trend at national level. They cover around 9,550 ha (Milić et al., 2018), where within the sowing structure are dominant cereals and fruit, while vegetables are present at small areas, up to couple hundred hectares (Sojić, 2017). Besides, some estimations show that organically produced cabbage covers just several hectares.

On the other hand, traditionally sauerkraut has played a significant role in the dietary habits of the European population, especially during the winter. It is estimated that in certain countries it involves more than $70 \%$ of total fresh cabbage production, as well as consumption per capita of around $4 \mathrm{~kg}$ (in Eastern Europe region). Besides production, in Serbia the most of fresh cabbage is processed (fermented) at small family farms and households. Within the volume of market-oriented sauerkraut, 50\% ends up in retail, while the rest is realized through the green market or direct sales at the farm gate (Simović, 2010).

Usually, sustainable agriculture is turned to the ability of agricultural systems to handle the high crop or animal productivity over the long period, while they are flexible enough to adapt to expecting changes. In essence, sustainable agriculture is mainly characterized by maintaining of environmental quality, stable crop or animal productivity and social acceptability (Đokić, 2019).

Besides, there is a need for reconsideration of long-term farm sustainability, as well as certain factors that affect it (D'souza et al., 1993; Baccar et al., 2019): farms' size and economic strength; production orientation; level of specialization; age and number of farm members; availability of natural and production resources; level of farmers' education and readiness for tech-tech transfer, knowledge and skills improvement, or added value creation; level of awareness linked to environmental issues; etc.

In function of strengthening the farm sustainability is also the availability of specific agricultural and/or food products, or services that carry within themselves certain level of added value, and that can be successfully realized at the local or regional market. They can be the result of either production specialization or diversification of farm activities.

During the previous decades, farmers seriously fight to find the right way to increase their income throughout the process of "adding value" to raw agricultural products they produce. There are a number of methods for that, such are: cleaning, cooling, packaging, labelling, processing, distributing, churning, grinding, hulling, extracting, drying, smoking, handcrafting, etc. So contemporary farm business recognizes the adding value as "selling the sizzle, not the steak", where the sizzle is the product of information, education, entertainment, image, and other intangible attributes (Born, Bachmann, 2006). 
In support of previously mentioned is the business philosophy of "niche marketing", which refers to the realization of a specific product at the relatively small but welldefined market segment, such are certain geographical territory, specialized sector of industry, or certain ethnic, religious, age, gender or some other consumers' group. As example could be noted local traditionally produced products or products with geographical origin, organic products, or foodstuff intended for vegetarians or sportsmen (Anzaku, Salau, 2017).

From the farmer's perspective, value added represents a portfolio of agricultural activities and practices by which they want to maximally adjust their agro-food products and services with the preferences of end-consumers. Value-added is available to farmers who are improving their position within the supply chain, moving closer to the end-consumers, or making changes or advancements within the existing production process in order to change, point up or preserve certain characteristics of their products (Coltrain et al., 2000).

\section{Used methodology and data sources}

All necessary data used for analytical calculations are obtained from family farm traditionally oriented to vegetable production and vegetable processing, located in South-Banat District. It has to be noted that farm is involved in conventional vegetable production and further processing, while large share in produced vegetable has cabbage production. Collected data refers to production year 2018. Besides, it's also used the secondary data of SORS, scientific and professional literature oriented to the researched field of production and processing.

Main research goal is comparison of economic effects (incomes and variable costs) gained in sauerkraut production during one year based on the use of conventionally and organically produced cabbage. Economic effects are reconsidered and compared throughout the preparation of analytical calculations based on variable costs (contribution margin).

Calculation of contribution margin linked to the production of certain crop culture (including vegetables) or food product (food processing) considers subtracting of variable costs from incomes generated within the observed production line (Nastic et al., 2018). Character of variable costs in food (vegetable) processing mainly have used inputs and services, such are fresh vegetable, salt or certain additives, water, energy, external services and engaged labour, etc.

Better comparison is enabled by the tabular presentation of all data and economic results (in RSD) for the total volume of sauerkraut production (volume of processed cabbage at the farm is unified and limited by the capacity of production space and used equipment). 


\section{Results with discussion}

The analysis of economic justification of sauerkraut production is based on the data obtained from a registered family farm that has been active in the vegetable sector for many years. The farm is located in the South-Banat District, at the territory of the Pančevo city. Production is dominantly turned to ecologically oriented growing (in line to strict use of the GAP principles) of cucumbers and tomatoes in greenhouse, as well as production of cabbage and other Brassicaceae plants in the open field. The most of the produced vegetables is selling as fresh throughout the local green market or at farm gate. Besides, certain volume of vegetables is transformed through the processing into the higher value products (such as sauerkraut, pasteurized tomato juice, pickles, hot ketchup, torshi, etc.). They are selling throughout the local retail, green market, or at farm gate.

In the focus of this paper is a comparative analysis of the economic justification of processing (pickling) of cabbage produced within the conventional or organic system of production. Since the farm has many years of experience in cabbage processing (sauerkraut production), according the fact that processing of cabbage produced in any production system requires the same equipment, technological approach and norms of used inputs, it would be interesting to consider economic effects initiated by changing of the basic input (cabbage) within the process of sauerkraut production.

Starting the process of cabbage processing at the farm in the volume of around $16 \mathrm{t}$ of fresh cabbage per year (split into the two cycles), requires certain level of investments in infrastructure equipment of processing facility (electrification, access to fresh water and drainage of technical water, thermal insulation, lining the ceramic tiles, etc.), as well as purchase of required equipment. Total sum needed for that purpose is almost 2,115,000 RSD, or approximately 18,000 EUR (1 EUR = 117,5 RSD).

Organizing the cabbage processing at the farm involves a production facility of approximately $65 \mathrm{~m}^{2}$ consisted from at least three separate rooms (with space for pickling, for manipulation under the inputs and final product, and for cold storing of the packed final product).

Required equipment includes: 15 barrels (from industrial plastic, with the capacity of 1,000 1); worktable (acid-resistant); vacuum machine (two-chambers); cabbage cutting machines (with working parts of stainless steel); set of knifes; 30 plastic water weights ( $5 \mathrm{~kg}$ each); 5 plastic containers (with the capacity of up to 20 $\mathrm{kg}$ ); 2 digital weighing scales (up to $40 \mathrm{~kg}$ ); 4 fine polished wooden pallets for sauerkraut squeezing; cart; etc. (Subić, Tomić, 2019). 
Short description of used technology in the sauerkraut production, as well as incomes, costs and contribution margin gained throughout the pickling of organically and conventionally produced cabbage, are given in the following table (Table 2.).

Table 2. Contribution margin in sauerkraut production

\begin{tabular}{|c|c|c|c|c|c|c|c|}
\hline \multirow{2}{*}{ Element } & \multirow{2}{*}{ U.M. } & \multicolumn{3}{|c|}{$\begin{array}{l}\text { Sauerkraut from conventionally } \\
\text { produced cabbage }\end{array}$} & \multicolumn{3}{|c|}{$\begin{array}{c}\text { Sauerkraut from organically } \\
\text { produced cabbage }\end{array}$} \\
\hline & & Quantity & $\begin{array}{l}\text { Price/UM } \\
\text { (in RSD) }\end{array}$ & $\begin{array}{c}\text { Total } \\
\text { (in RSD) }\end{array}$ & Quantity & $\begin{array}{l}\text { Price/UM } \\
\text { (in RSD) }\end{array}$ & $\begin{array}{c}\text { Total } \\
\text { (in RSD) }\end{array}$ \\
\hline \multicolumn{8}{|l|}{ I Incomes } \\
\hline Sauerkraut & $\mathrm{kg}$ & 12,000 & 70 & 840,000 & 12,000 & 160 & $1,920,000$ \\
\hline Subsidies & pack. & & & - & & & - \\
\hline \multicolumn{4}{|c|}{ Value of production (total I) } & 840,000 & & & $1,920,000$ \\
\hline \multicolumn{8}{|l|}{ II Variable costs } \\
\hline Cabbage & $\mathrm{kg}$ & 15,750 & 17.5 & 275,625 & 15,750 & 75 & $1,181,250$ \\
\hline Salt & $\mathrm{kg}$ & 600 & 140 & 84,000 & 600 & 140 & 84,000 \\
\hline Foil & pcs & 30 & 275 & 8,250 & 30 & 275 & 8,250 \\
\hline Vacuum bag & pes & 6,000 & 7.5 & 45,000 & 6,000 & 8,5 & 51,000 \\
\hline Transport box & pes & 400 & 55 & 22,000 & 400 & 55 & 22,000 \\
\hline Labour & $\mathrm{h}$ & 408 & 270 & 110,160 & 408 & 270 & 110,160 \\
\hline Energy & - & - & - & 27,000 & - & - & 27,000 \\
\hline Water & - & - & - & 1,800 & - & - & 1,800 \\
\hline Dez \& Der & - & - & - & 9,500 & - & - & 9,500 \\
\hline Quality control & - & - & - & 8,500 & - & - & 10,500 \\
\hline Certification & - & - & - & - & - & - & 118,000 \\
\hline Taxes & - & - & - & 6,750 & - & - & 6,750 \\
\hline Other costs & - & - & - & 6,250 & - & - & 6,250 \\
\hline \multicolumn{4}{|c|}{ Sum of variable costs (total II) } & 604,835 & & & $1,636,460$ \\
\hline \multicolumn{4}{|c|}{ III Contribution margin (I-II) } & 235,165 & & & 283,540 \\
\hline
\end{tabular}

Source: IAE, 2019.

Hereinafter, it will be given certain clarifications regarding the data shown in previous table (Table 2.). The season of production and sale of sauerkraut is framed by the period September - January. Technological process of sauerkraut production lasts for 20-25 days. As was previously mentioned, farm has on disposal 15 barrels, where each barrel is used twice during the season of sauerkraut production (annual production is technically limited to 30 barrels).

For processing is used self-produced or from local vegetable growers purchased first class fresh cabbage. It's shown the average wholesale price of fresh cabbage 
(conventionally and organically produced) that includes its delivery to farm. One season of cabbage pickling requires the purchase of $15,750 \mathrm{~kg}$ of fresh cabbage.

After the purchase, fresh cabbage is mechanically cleaned (stripping the outer leaves), and preparing for pickling (cutting the root or chopping the heads into the small pieces). With this activity, the volume of fresh cabbage that enters the pickling process is reduced for $5 \%$. Each barrel could receive $500 \mathrm{~kg}$ of fresh cabbage, where during the pickling process volume of cabbage is additionally reduced for $20 \%$. So after the draining around $12,000 \mathrm{~kg}$ of final product could be packaged (in vacuum bags and shipping boxes) and sold usually to local retailer.

In addition to fresh cabbage, a solution of water and table salt is adding into the barrel. Then, the barrel is tucked in well by the foil and additionally loaded with plastic water weights. Share of salt within the structure of production mass is about $2 \%$, i.e. each barrel contains $20 \mathrm{~kg}$ of salt. Salt is buying in bulk in $5 \mathrm{~kg}$ bags. As was previously mentioned, the process of pickling requires the use of a foil for the barrel sealing, in order to preserve necessary conditions for cabbage fermentation (new foil is placed during the each filling of the barrel).

Sauerkraut is delivering at the market in vacuum bags (with printed data about the producer and products' declaration) in volume of $1-2 \mathrm{~kg} / \mathrm{bag}$. Vacuum bags are additionally packaged in plasticized cardboard boxes ( 15 bags/box).

Labour costs consider the occasional engagement of two persons for the realization of several processing activities. Although the labour costs (the most often only costs of external labour are used (Subic, Jelocnik, 2019)) may or may not burden the analytical calculation of contribution margin, in order to better perceive the effects that arise from cabbage processing, they are fully shown within the structure of variable costs . Working staff is represented by a farmer and external worker, where the gross wage per working hour accounts around 270 RSD.

The process of filling the barrels with fresh cabbage (cleaning, cutting, chopping and stacking of the cabbage, pouring the brine and sealing the barrels) requires in total the fund of 168 working hours. Taking out the sauerkraut from the barrels and its stacking at the wooden pallets for further draining (before packing the sauerkraut is pyramidally stacked at the pallets and left to drain for next 24 hours) requires in total the 120 working hours. Packing (vacuuming) of sauerkraut and its transfer to cold storage requires additional 120 working hours. So, the total labour (for the whole season) requires the fund of 408 working hours.

Production of sauerkraut is additionally burdened with the costs of electricity (for lighting, heating of the working facility, for operation of the cold storage 
and used equipment, etc.), water costs (for the use of fresh water and disposal of wastewater), costs of disinfection and pest control within the facility, costs of final product quality control (verification of the product declaration), costs of taxes and fees, and other costs.

In order to mark the final product of processing with the tag representing it as a organic, production of sauerkraut based on organic cabbage has to be previously certified (certification of technological process, i.e. used facility and equipment) by authorized certification body. Besides, processor has to proof that the input he uses in pickling is produced in organic system.

So, within the processing of organic products are used just certified inputs. If parallel with the processing of conventional inputs, processing line of organic inputs wants to be established, the entire technological process must be separated in time or space. Also, before the beginning of organic products processing, all equipment must be precleaned with allowed cleanser. In addition, mixing of organically and conventionally produced inputs and final products of processing is not allowed. It can be used only by the regulative on organic production allowed additives, excipients, minerals, etc. Domestic processed certified organic products may be labelled with the national organic product sign and logo of the inspection body that previously certified the primary product (input) if the final product of processing contains minimum $95 \%$ of ingredients of agricultural origin produced in line to principles of organic production (Serbia Organica, 2019).

According to previously mentioned next could be concluded:

- In both processing lines are gained positive contribution margin.

- Under the same processing capacity, the contribution margin achieved in processing of organically produced cabbage is for more than $20 \%$ higher than achieved one in processing of conventionally produced cabbage.

- Initiation of processing of organically produced cabbage needs much higher amount of financial assets (2.7 times higher). Besides, achieved incomes are 2.3 times higher.

- In both lines, in the structure of variable costs dominate the costs of fresh cabbage (in processing of organically produced cabbage even $72 \%$ ).

\section{Conclusion}

Cabbage production has long tradition at the territory of Serbia. As primary product gained from cabbage processing, sauerkraut is unavoidable food product, especially 
during the winter time. On the other hand, areas under organically produced vegetable, specifically cabbage, currently are below production capabilities and market demand.

In paper were tested and compared contribution margins gained in sauerkraut production based on the use of organically or conventionally produced cabbage, as mentioned productions require identical production process and equipment. Obtained results show that for certain farm, processing of organic cabbage could be for $20 \%$ more profitable, although starting of its conduction (purchasing of inputs) requires much higher amount of financial assets.

This could be such important information given the assumption that the needs at national niche market for organic sauerkraut are much greater than currently possible production. This is crucial for two reasons. Firstly, mentioned can pull organic cabbage producers to expand their production areas and offer fresh cabbage to farms that are already active in cabbage processing. By this processors could additionally engaged their available processing capacity to maximal level, reaching at that way the higher grade of profitability and economic sustainability. Secondly, producers of organic cabbage can divers their production activity with introduction of cabbage processing at the farm. By that they could contribute to maintaining and increase of farm income, especially in years with low sales price of fresh organic cabbage. Thirdly, any farm active only in the segment of cabbage processing (whether organic or conventional cabbage), with presented capacities cannot provide its own, primarily financial sustainability (gained incomes and contribution margins are too low for maintaining of decent life for farm members). In line to the volume of produced final product, required work engagement and possible incomes, cabbage processing could be just in function of secondary (additional) activity at the farm.

\section{References}

1. Anzaku, T. A. K., Salau, E. S. (2017). Niche marketing potentials for farm entrepreneurs in Nigeria. Journal of Agricultural Extension, 21(3):136-142.

2. Baccar, M., Bouaziz, A., Dugué, P., Gafsi, M., Le Gal, P. Y. (2019). The determining factors of farm sustainability in a context of growing agricultural intensification. Agroecology and Sustainable Food Systems, 43(4):386-408.

3. Born, H., Bachmann, J. (2006). Adding value to farm products: An overview. ATTRA - National Sustainable Agriculture Information Service, Fayetteville, USA, pp. 1-12.

4. Červenski, J., Medić-Pap, S. (2018). Proizvodnja kupusa. monografija, Institut za ratarstvo i povrtarstvo, Novi Sad, Srbija. 
5. Coltrain, D., Barton, D., Boland, M. (2000). Value Added: Opportunities and Strategies. Arthur Capper Cooperative Center, Department of Agricultural Economics, Kansas State University, Manhattan, USA.

6. Cvetković, B. (2014). Primena tehnoloških postupaka spontane fermentaciji $i$ osmotske dehidratacije za unapređenje nutritivnog profila, senzornih svojstava i održivosti kupusa, doktorska disertacija, Tehnološki fakultet, Univerziteta u Novom Sadu, Novi Sad, Srbija.

7. D'souza, G., Cyphers, D., Phipps, T. (1993). Factors affecting the adoption of sustainable agricultural practices. Agricultural and Resource Economics Review, 22(2):159-165.

8. Đokić, M. (2019). Sustainable agricultural and rural development in the European Union. Economics of Sustainable Development, 3(1):29-43.

9. GRS (2019). Zaključak o usvajanju IPARD programa za Republiku Srbiju za period 2014-2020. Godine. Vlada Republike Srbije, Beograd, Srbija, Sluzbeni glasnik Republike Srbije, br. 30/2016-3, 84/2017-30, 20/2019-22, 55/2019-55.

10. IAE(2019). Field data related to cabbage processing (sauerkrautproduction). Internal data, Institute of Agricultural Economics (IAE), Belgrade, Serbia.

11. Milić, D., Lukač Bulatović, M., Milić, D. (2018). Uporedna analiza organske proizvodnje voća u Evropskoj uniji i Srbiji. Agroekonomika, 47(80):13-22.

12. Nastić, L., Jeločnik, M., Subić, J. (2018). Contribution margin in silage maze production. Ekonomika, 64(4):71-80.

13. Serbia Organica (2019). Prerada organskih proizvoda. Portal Serbia Organica (National Association for Organic Production), Belgrade, Serbia, available at: https://serbiaorganica.info/prerada-organskih-proizvoda/\#, retrieved at: 28.9.2019.

14. Simović, Đ. (2010). Kvalitetan sortiment za kiseli kupus. portal Poljoprivreda. info, available at: https://poljoprivreda.info/tekst/kvalitetan-sortiment-zakiseli-kupus

15. Sojić, S. (2017). Kreiranje brenda organskih poljoprivredno-prehrambenih proizvoda u Republici Srbiji. doktorska disertacija, Univerzitet u Novom Sadu, Poljoprivredni fakultet, Novi Sad, Srbija.

16. SORS (2019). Data related to cabbage and kale production for the period 2012-2018. portal of the Statistical Office of the Republic of Serbia (SORS), Belgrade, Serbia, available at: https://data.stat.gov.rs/Home/ $\underline{\text { Result } / 130102 \text { ?languageCode }=\text { sr-Cyrl }}$ 
17. Subić, J., Jeločnik, M. (2019). Economic Effectiveness of Ecologically Acceptable Production of Vegetables in Protected Area. In: Sustainable Agriculture and Rural Development in Terms of the Republic of Serbia Strategic Goals Realization within the Danube Region: Sustainability and Multifunctionality, thematic proceedings, (Eds.) Subić, J., Kuzman, B., Jeločnik, M., Vasile, A. Institute of Agricultural Economics, Belgrade, Serbia, pp. 333-352.

18. Subić, J., Tomić, V. (2019). Programi investicija u preradu bezbedne hrane na malim poljoprivrednim gazdinstvima za mleko, meso, voće i povrće. In: Unapređenje transfera znanja radi dobijanja bezbednih i konkurentnih poljoprivrednih proizvoda, koji su dobijeni preradom na malim gazdinstvima u sektorima mleka, mesa, voća i povrća, (Edt.) Kovačević, V., monograph, Institute of Agricultural Economics, Belgrade, Serbia, pp. 93-158. 